\section{Loyalitas Kreativitas \\ Aldi Masyarakat Kreatif}

P-ISSN 2722-2101, E-ISSN 2722-4201

Program Studi Ekonomi Manajemen Universitas Pamulang

Jurnal LOKABMAS Kreatif Vol. 01, No. 01, Hal. 96-99

Email:jurnalkreatif.manajemen@gmail.com

\title{
PERAN AKUNTANSI DALAM PENGAMBILAN KEPUTUSAN MANAJERIAL DALAM RANGKA MENCAPAI TUJUAN ORGANISASI
}

\author{
Andri Priadi , Styo Budi Utomo, Agrasadya, Deni Diana \\ Dosen Ekonomi Fakultas Ekonomi Universitas Pamulang
}

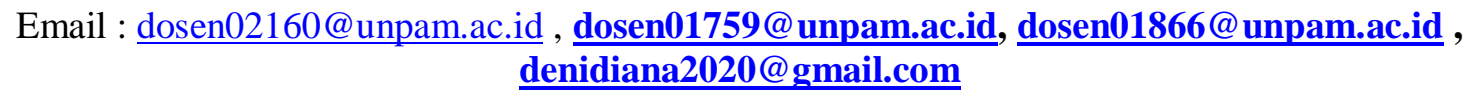

\begin{abstract}
ABSTRAK
Peran akuntasi dalam pengambilan keputusan manajerial dalam rangka mencapai tujuan organisasi adalah judul dari kegiatan PKM di SMK Darussalam Ciputat Kota Tangerang Selatan Banten.

Adapun tujuan kegiatan Pengabdian Kepada Masyarakat (PKM) ini adalah membekali siwa-siswi terkait pentingnya keahlian dalam dunia kerja yang serba digital.

Dalam kegiatan ini siswa-siswi kelas XI jurusan akuntansi SMK Darussalam Ciputat sebagai objek/tujuan kegiatan ini. Kegiatan ini memberikan pengarahan dan penjelasan tentang peran pentingnya akuntansi dalam mencapai tujuan organisasi. selain teori, dalam kegiatan ini juga praktik agar siswa-siswi mengetahui penggunaan akuntansi dan pentingnya akuntasi dalam sebuah perusahaan/organisasi.
\end{abstract}

\section{Kata Kunci: Akuntasi, Pengambilan keputusan, tujuan organisasi}

\section{ABSTRAC}

The role of accounting in managerial decision making in order to achieve organizational goals is the title of the PKM activities in Ciputat City of South Tangerang, Banten.

The purpose of this Community Service (PKM) activity is to equip students regarding the importance of expertise in the digital world of work.

In this activity class XI students majoring in accounting at SMK Darussalam Ciputat as the object / purpose of this activity. This activity provides direction and explanation on the important role of accounting in achieving organizational goals. In addition to theory, in this activity also practices so that students know the use of accounting and the importance of accounting in a company / organization.

Keywords: Accounting, Decision making, organizational goals

\section{PENDAHULUAN}

Seiring dengan perkembangan zaman, pendidikan pun menuntut agar para alumni sekolah SMK mempunyai kehalian yang dapat diimplikasikan kedalam keseharian maupun dalam dunia kerja. Kehalian tersebut tidak mudah untuk mengukir dan membentuk pada diri siswa. Tetapi hanyasiswa tersbutlah yang dapat memproses diri mereka dengan berbagai keilmuan dan ketrampilan.
Sebelum siswa siswi lulus maka pihak sekolah harus membekali dengan materi teori dan praktik. Dalam materi praktik khususnya aplikasi akuntansi pada jurusan Akuntansi SMK Darussalam haruslah diperkenalkan agar dapat diimplikasikan dalam dunia kerja dikemudian hari.

Dengan adanya materi ini tentang bagaimana diharapkan siswa mampu mengenal dan mempraktikan serta 


\section{Loyalitas Kreativitas \\ Aldi Masyarakat Kreatif}

P-ISSN 2722-2101, E-ISSN 2722-4201

Program Studi Ekonomi Manajemen Universitas

Pamulang

Jurnal LOKABMAS Kreatif Vol. 01, No. 01, Hal. 9699

Email:jurnalkreatif.manajemen@gmail.com mengimplementasikan dalam dunia kerja. Perlu adanya dukungan dan pihak yayasan untuk menjalankan pelatihan ini agar tersampaikan dengan maksimal.

\section{RUMUSAN MASALAH}

Dengan mempertimbangkan latar belakang yang telah diutarakan diatas kami berinisiatif untuk membentuk kegiatan pengabdian masyarakat bagi siswa-siswi SMK Darusaalam jurusan Akuntansi.

Membekali siswa - siswi dengan pengenalan aplikasi akuntansi agar mudah dipahami dan mampu mengelola,membuat terkait pelaporan -pelaporan secara mandiri dan professional.

\section{TUJUAN PELAKSANAAN}

1. Membantu memberikan arahan pada siswa - siswi SMK Darussalam khususnya kelas XII jurusan akuntansi.

2. Membuka paradigma siswa-siswi terkait dengan informasi akuntansi.

3. Memberikan semangat dan motivasi bagi siswa-siswi SMK Darussalam dalam meniti karir di kemudian hari.

\section{TINJAUAN PUSTAKA}

\section{Pengertian Peran}

Peran adalah serangkaian pola perilaku yang diharapkan dari seseorang atau sistem, karena seseorang atau sistem tersebut memegang posisi tertentu dalam suatu unit usaha atau suatu organisasi. sedangkang akuntansi adalah sebagai variable yang mempenagruhi manajer dalam bertindak. sesuai dengan pendapat Robins dalam Bambang (2012) menjelaskan bahwa: "Role is a set of expected behavior patern attributed to some one occupying a given position in a socia unit" yang artinya bahwa peran merupakan seperangkat pola perilaku yang melekat pada seseorang, karena menyandang posisi atau jabatan tertentu dalam masyarakat.

\section{Pengertian Manajerial}

Pada dasarnya, kata manajerial adalah kata benda yang melekat pada seorang manajer. Dalam Kamus Besar Bahasa Indonesia (KKBI) kata manajerial berhubungan dengan manajer keterampilan yang tinggi sangat diperlukan bagi setiap pemimpin. Jadi manajerial adalah sebuah posisi/jabatan seseorang dalam struktur organisasi. sedangakan kata manajer adalah orang yang melakukan atau mengatur pekerjaan untuk kerja sama di antara berbagai kelompok atau sejumlah orang untuk mencapai sasaran/tujuan oragnisasi.. Manajemen dalam organisasi mempunyai beberapa fungsi manajemen dibagi menjadi tiga, yaitu:

\section{Perencanaan (planning)}

Dalam perencanaan ini seornag menejer harus memikirkan apa yang akan dilakukan dengan sumber daya yang tersedia dalam organisasi. Perencanaan dalam semua kegiatan organiasasi merupakan proses terpenting dari semua fungsi fungsimanajemen

\section{Pengorganisasian (organizing)}

Pengorganisasian adalah suatu kegiatan dengan cara membagi kegiatan dari yang besar menjadi kegiatan yang lebih kecil dengan tujuan agar masing-masing individu atau kelompok lebih mudah untuk mengerjkan dan mencapai tujuan.. Pengorganisasian dapat juga dilakukan dengan cara menentukan tugas, wewenang dan htanggung jawab serta tingkat pengambilan keputusan.

\section{Pengarahan (directing)}




\section{Loyalitas Kreativitas \\ Aldi Masyarakat Kreatif}

P-ISSN 2722-2101, E-ISSN 2722-4201

Program Studi Ekonomi Manajemen Universitas

Pamulang

Jurnal LOKABMAS Kreatif Vol. 01, No. 01, Hal. 96-

Email:jurnalkreatif.manajemen@gmail.com

Pengarahan adalah suatu tindakan untuk mengusahakan agar semua anggota kelompok berusaha agar dapat mencapai sasaran sesuai dengan perencanaan manajerial dan usaha.

4. Pengawasan (controlling)Adalah tindakan dalam sebuah tanggungjawab pada operasional pekerjaan baik pekerjaan sedang dilakukan maupun telah selesai dikerjakan yang mengacu pada tujuan dari pengorganisasian.

\section{.METODE PELAKSANAAN}

Metode kegiatan yang digunakan dalam kegiatan PKM ini menggunakan beberapa cara, antara lain :

1. Penyampaian materi dengan menggunakan video/ppt

2. Metode persentasi/ceramah, metode ini bertujuan agar siswadapat memehamai dan menerima informasi tentang penyampaian materi.

3. Metode Praktikum, metode ini bertujuan agar siswa mampu lebih memahami dan tidak sekedar anganangan (teori)

4. Metode tanya jawab, adalah metode yang digunakan untuk merespon sejauh mana tingkat pemahaman peserta tentang materi yang telah disampaikan oleh narasumber.

5. Metode diskusi, adalah metode yang digunakan untuk memecahkan setiap permasalahan yang dikemukakan oleh peserta

\section{HASIL DAN PEMBAHASAN}

Pengabdian KEpada Masyarakat

(PKM) Universitas Pamulang yang dilakukan oleh para dosen pada program studi Manajemen telah berjalan dengan lancar dan mendapat sambutan hangat dari para siswa maupun dari pihak guru serta masyarakat sekolah tentunya dalam tempat pelaksanaan kegiatan ini yaitu di SMK Darussalam Ciputat, Tangerang Selatan.

Besar harapan kami dengan pengabdian ini dapat pandangan para siswa untuk mengahadapi dunia kerja setelah lulus sekolah kelak juga untuk memikirkan dan merencanakan serta menggapai citacita dari masing-masing siswa. Dengan melalui kegiatan ini semoga mereka dapat ilmu yang diperoleh dari pada kegiatan Pengabdian Masyarakat ini. Dan diharapkan mampu memberikan semangat baru bagi kita dalam menyampaikan materi dan motivasi serta berkontribusi bagi generasi muda, baik dilingkungan sekolah, kampus dan keluarga.

\section{KESIMPULAN DAN SARAN \\ Kesimpulan}

Para siswa sangat antusias dalam kegiatan ini. Tampak jelas setelah beberpa siswa diberi kesempatan untuk menilai dari kegiatan ini, serta siswa juga menyebutkan rencana kedepannya setelah lulus sekolah kelak.

\section{Saran}

Selesainya kegian PKM ini diharapkan siswa terus belajar dan mengikuti perkembangan teknologi apalagiteknologi yang berkaitan dengan dunia kerja. Oleh karena itu siswa diharapkan terus membuka wawasan dan cara pandang dalam menghadapi dunia yang nyata yaitu dimana mereka setelah lulus sekolah.

\section{DAFTAR PUSTAKA}

Charles T. Hornren, Pengantar Akuntansi Manajemen, Penerbit

Erlangga,Jakarta,2007.

Hansen/Mowen, Akuntansi Manajemen, penerbit Salemba Empat, Jakarta, 2005 -Manajemen Biaya, PenerbitSalemba Empat, Jakarta, 2005. 


\section{Loyalitas Kreativitas \\ Aldi Masyarakat Kreatif}

Email:jurnalkreatif.manajemen@gmail.com

Hendry Simamora, Akuntansi Manajemen, penerbit Salemba Empat, Jakata, 2005

Kusnadi, Zainul Arifin, Moh. Syadeli, Akuntansi Manjemen. Universitas Brawijaya, Malang, 2005.Mulyadi, Akuntansi Manajemen Edisi 3, Penerbit Salemba Empat, Jakarta, 2007

Suedi,Bambang,

https://www.neliti.com/id/publications/134 332/peranan-akuntansi-manajemen-dalampengambilan-keputusan-manajerial

Pasaribu, V. L. D., Agrasadya, A., Shabrina, N., \& Krisnaldy, K. (2020). MENJADI ENTERPRENEUR MUDA YANG MEMILIKI JIWA LEADERSHIP UNTUK MENGHADAPI MASA DEPAN. Abdi Laksana, 1(1)

Pasaribu, V. L. D., Elburdah, R. P., Sudarso, E., \& Fauziah, G. (2020). PENGGUNAAN MANAJEMEN WAKTU TERHADAP PENINGKATAN PRESTASI BELAJAR DI SMP ARAISIYAH. Jurnal ABDIMAS, I(1)

Pasaribu, V. L. D., Susanti, F., \& Hartuti, E. T. K. (2019). MEMOTIVASI SISWA DAN SISWI SMK LETRIS INDONESIA DI DALAM MENENTUKAN PILIHAN UNTUK MELANJUTKAN PENDIDIKAN ATAU BEKERJA SETELAH LULUS SEKOLAH. Jurnal Pengabdian Dharma Laksana, 1(2), 161172.

\section{DOKUMENTASIFOTO KEGIATAN}
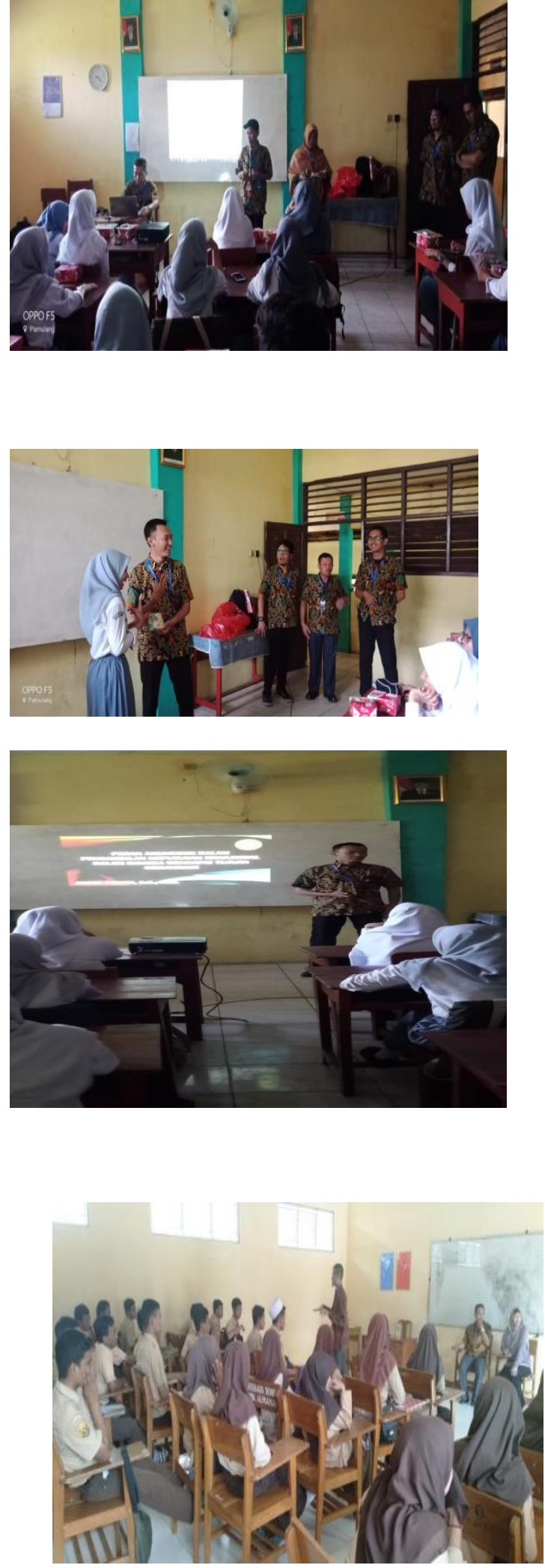
Loyalitas Kreativitas

Aldi Masyarakat Kreatif
P-ISSN 2722-2101, E-ISSN 2722-4201

Program Studi Ekonomi Manajemen Universitas

Pamulang

Jurnal LOKABMAS Kreatif Vol. 01, No. 01, Hal. 9699

Email:jurnalkreatif.manajemen@gmail.com 